\title{
Ecological Baseline Study of the Yakima Firing Center Proposed Land Acquisition: A Preliminary Report
}

L. E. Rogers, Principal Investigator
P. A. Beedlow
D. D. Dauble
L. E. Eberhardt
R. E. Fitzner

February 1988

Prepared for the U.S. Army under a Related Services Agreement with the U.S. Department of Energy under Contract DE-AC06-76RLO 1830

Pacific Northwest Laboratory Operated for the U.S. Department of Energy by Battelle Memorial Institute 


\title{
DISCLAIMER
}

This report was prepared as an account of work sponsored by an agency of the United States Government. Neither the United States Government nor any agency thereof, nor Battelle Memorial Institute, nor any or their employees, makes any warranty, expressed or implied, or assumes any legal liability or responsibility for the accuracy, completeness, or usefulness of any information, apparatus, product, or process disclosed, or represents that its use would not infringe privately owned rights. Reference herein to any specific commercial product, process, or service by trade name, trademark, manufacturer, or otherwise does not necessarily constitute or imply its endorsement, recommendation, or favoring by the United States Government or any agency thereof, or Battelle Memorial Institute. The views and opinions of authors expressed herein do not necessarily state or reflect those of the United States Government or any agency thereof, or Battelle Memorial Institute.

\author{
PACIFIC NORTHWEST LABORATORY \\ operated by \\ BATTELLE MEMORIAL INSTITUTE \\ for the \\ UNITED STATES DEPARTMENT OF ENERGY \\ under Contract DE-AC06-76RLO 1830
}

\begin{tabular}{|c|c|}
\hline \multicolumn{2}{|c|}{ Printed in the United States of America } \\
\hline \multicolumn{2}{|c|}{ Available from } \\
\hline \multirow{2}{*}{\multicolumn{2}{|c|}{$\begin{array}{l}\text { National Technical Information Service } \\
\text { United States Department of Commerce }\end{array}$}} \\
\hline & \\
\hline \multicolumn{2}{|c|}{$\begin{array}{c}5285 \text { Port Royal Road } \\
\text { Springfield, Virginia } 22161\end{array}$} \\
\hline \multicolumn{2}{|c|}{ Springfield, Virginia 22161} \\
\hline \multirow{2}{*}{\multicolumn{2}{|c|}{$\begin{array}{l}\text { NTIS Price Codes } \\
\text { Microfiche A01 }\end{array}$}} \\
\hline & \\
\hline \multicolumn{2}{|c|}{ Printed Copy } \\
\hline & Price \\
\hline Pages & \\
\hline $001-025$ & $\mathrm{~A} 02$ \\
\hline 026-050 & $\mathrm{A} 03$ \\
\hline $051-075$ & A04 \\
\hline $076-100$ & A05 \\
\hline $101-125$ & $A 06$ \\
\hline $126-150$ & A07 \\
\hline $151-175$ & $\mathrm{~A} 08$ \\
\hline $176-200$ & A09 \\
\hline $201-225$ & A010 \\
\hline $226-250$ & A011 \\
\hline $251-275$ & A012 \\
\hline $276-300$ & A013 \\
\hline
\end{tabular}


PNL-6485

UC-11

ECOLOGICAL BASELINE STUDY OF THE YAKIMA FIRING CENTER PROPOSED LAND ACQUISITION: A PRELIMINARY REPORT

L. E. Rogers, Principal Investigator

P. A. Beedlow

L. E. Eberhardt

D. D. Dauble

R. E. Fitzner

February 1988

Prepared for the

U.S. Army under a Related Services Agreement with the U.S. Department of Energy Contract DE-AC06-76RLO 1830

Pacific Northwest Laboratory Richland, Washington 99352 


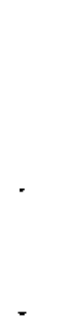

3 


\section{ACKNOWLEDGMENTS}

We would like to thank G. A. Sargeant of the Pacific Northwest Laboratory, who contributed to the collection and analysis of field data from the proposed Yakima Firing Center expansion area study site; $\mathrm{E}$. Anderson of Ft. Lewis and the Yakima Firing Center, who contributed to field data collection and observations; S. A. Eisner of the University of Montana, who contributed field data on bald eagle and watertowl sightings, and J. Blatt of Central Washington State University for his field assistance. In addition, G. M. Petrie, L. G. McWethy, C. S. Kimball, and G. E. Wukelic of PNL provided image processing and analysis. 
. 


\section{SUMMARY}

This preliminary report covers a baseline census conducted from October 1987 to January 1988 on the property identified for possible expansion of the Yakima Firing Center. These preliminary studies provide general descriptions of the major plant communities present and animal inhabitants during the late fall and winter study period. A vegetation map derived from a combination of onsite surveillance and remotely sensed imagery is also provided as part of this report.

Through January 1988,13 wildlife species of special interest to state and federal agencies, in addition to ducks and geese, were observed on the proposed expansion area. The area, as expected for this time of the year, is relatively poor in bird species. Ten raptorial bird species were observed in the proposed expansion area, including three of special interest: bald eagles, golden eagles, and prairie falcons. Upland game bird species, such as sage grouse, California quail, chuckars, and gray (Hungarian) partidge were present. A census of passerine birds will be conducted in the spring. However, loggerhead shrikes, a species of special interest, have already been observed on the site. Estimates of waterfowl abundance are included for the Priest Rapids Pool of the Columbia River, which includes the proposed river crossing sites. The number of waterfowl on the proposed crossing areas were comparatively low during the winter of 1986-87 and high in 1987-88. Bald eagles and common loons were observed on the proposed river crossing areas.

Six small mammal species were captured during this study period; one, the sagebrush vole, is a species of special interest. Two large animal species, mule deer and elk, were noted on the site. Beaver were the only furbearing animals noted to date. Rainbow trout were the only fish species collected within the proposed northern expansion area. The distribution of fall chinook salmon spawning areas was documented within the proposed river crossing areas.

Studies of the wildife, plants, and aquatic biota inhabiting the proposed northern expansion area are planned to continue. Information concerning the possible occurrence of sensitive plant species, wildlife distributions, breeding and nesting sites, and game fish and other aquatic species of interest will be provided in a later report. 
' 


\section{CONTENTS}

ACKNOWLEDGMENTS …............................................................... ii

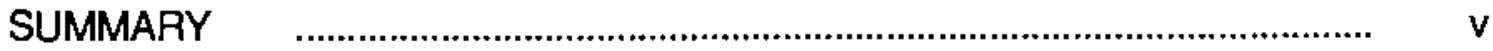

INTRODUCTION

VEGETATION SURVEY …….........................................................

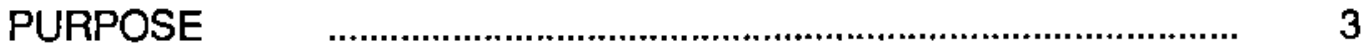

APPROACH

METHODS $\quad$......................................................................

PRELIMINARY RESULTS

WORK REMAINING

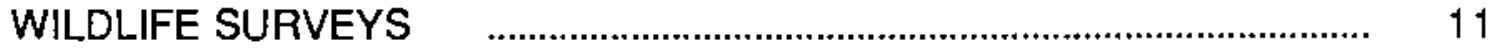

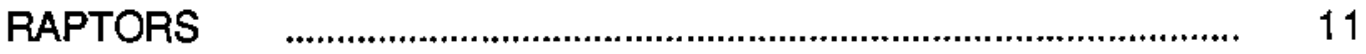

Methods ……….............................................................. 11

Results

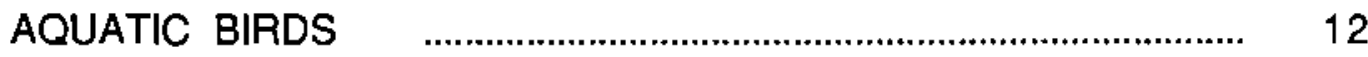

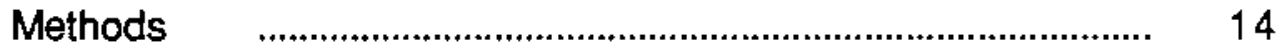

Results

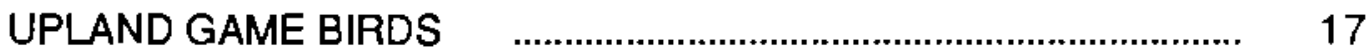

OTHER TERRESTRIAL BIRDS

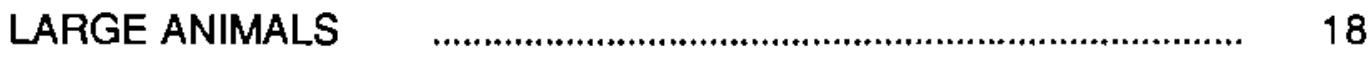

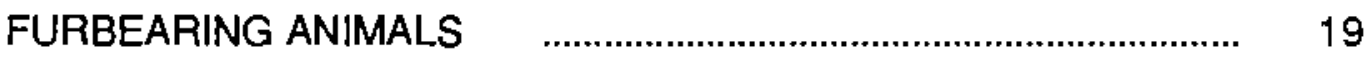

SMALL MAMMALS $\quad$.................................................................... 19

Methods …………............................................................ 19

Results $\quad$......................................................................... 19

SUMMARY OF WILDLIFE SURVEYS

FISHERIES SURVEYS

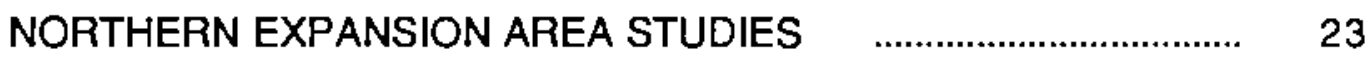

COLUMBIA RIVER CROSSING SITE $\quad$............................................... 25

REFERENCES

APPENDIX A - WILDLIFE SURVEY DATA TABLES ….............................. A. A

APPENDIX B - NUMBERS OF WATERFOWL OBSERVED ON THE PRIEST RAPIDS POOL OF THE COLUMBIA RIVER DURING THE WINTERS OF 1986-87 AND 1987-88 


\section{FIGURES}

1 Proposed Expansion Area of the Yakima Fining Center $\quad$.............. 2

2 Vegetation Distribution on the Expansion Area $\quad$............................. 7

3 Distribution of Bald Eagles During the Winters of 1986-87 and $1987-88$ on the Priest Rapids Pool of the Columbia River ..... 13

4 The Distribution of Waterfowl on the Priest Rapids Pool of the Columbia River for the Winters of 1986-87 and 1987-88

5 The Seasonal Distribution of Waterfowl on the Priest Rapids Pool of the Columbia River for the Winters of 1986-87 and 1987-88

6 The Distribution of Common Loons on the Priest Rapids Pool of the Columbia River

7 The Johnson Creek and Middle Canyon Drainages and Location of Winter Fish Populations

\section{IABLES}

1 Land Cover Classes of the Proposed Expansion Area

2 Summary of Wildlife Species of Special Interest Observed on the Proposed Expansion Areas to the Yakima Firing Center from October 1987 Through January 1988

3 Wildife Surveys Planned for the Proposed Expansion Areas to the Yakima Firing Center During the Spring and Summer of 1988 


\section{INTRODUCTION}

The U.S. Army is considering expanding the Yakima Firing Center (YFC) training facility (Figure 1). The expansion area would involve about 63,000 acres of rangeland. Most of the expansion area lies north of the present YFC, but a narrow right of way along the eastern boundary and two river crossing areas would also be included.

Although there is a lot of information in the open literature about the taxonomic and geographic status of the important plant and animal species of Washington, there is a paucity of information specific to the planned acquisition area. This study is intended to provide baseline information on the plants and wildlife inhabiting the acquisition area. Specific studies include 1) the distribution of vegetation types; 2) the distribution of key wildlife (e.g., raptors, sensitive bird species, waterfowl, game fish); 3) the distribution of sensitive plant species; and 4) game fish spawning and/or rearing areas near the river crossing sites.

This report is based on information gained from studies conducted from October 1, 1987, through January 22, 1988, and represents a preliminary assessment of the types and distribution of biota inhabiting the area. These studies are continuing. 


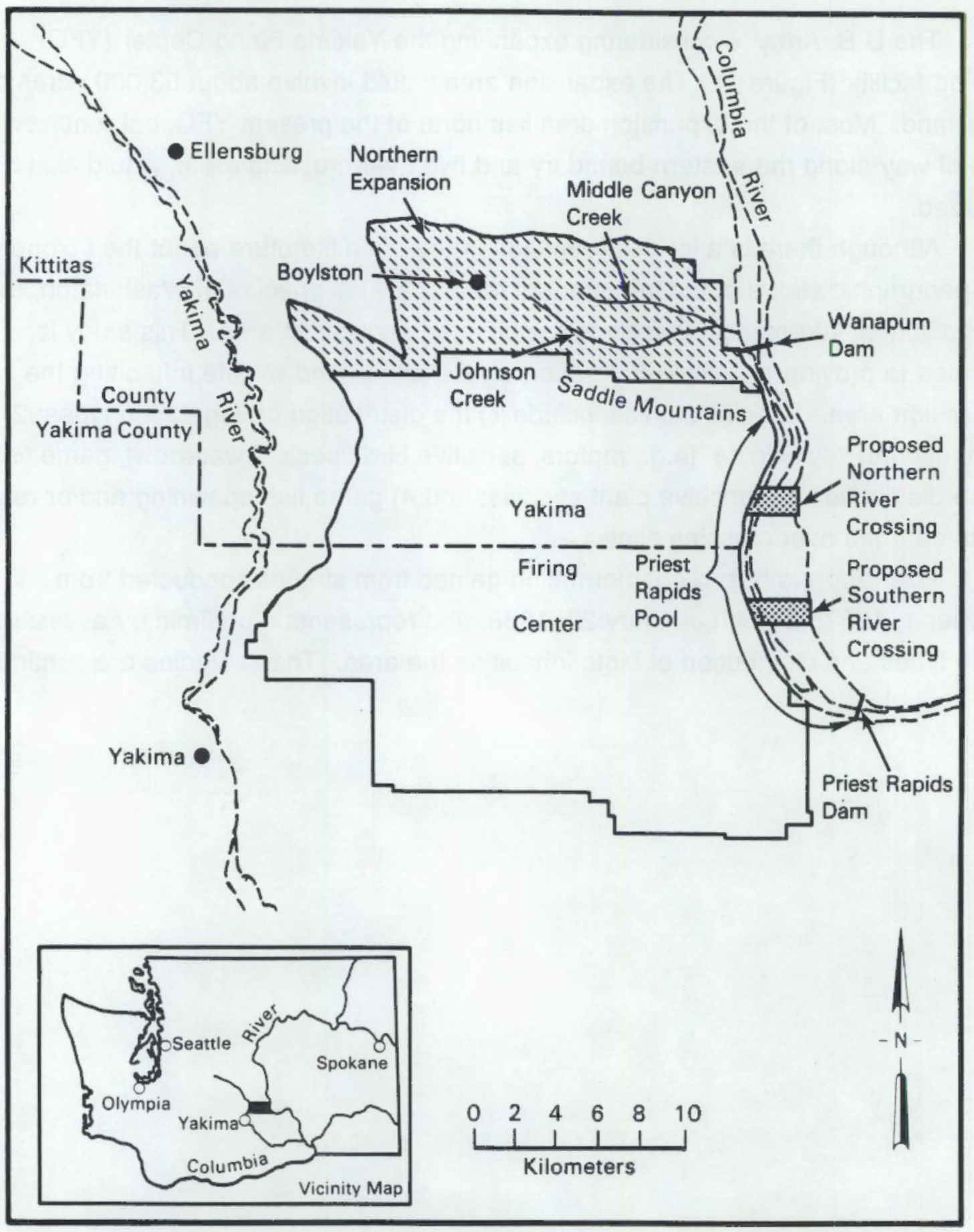

FIGURE 1. Proposed Expansion Area of the Yakima Firing Center 


\section{VEGETATION SURVEY}

\section{PURPOSE}

The purpose of the vegetation survey is to provide a preliminary estimate of the distribution and extent of the major vegetation types on the proposed acquisition area. The survey is not intended to characterize the vegetation types by species composition, biomass, density, or percent coverage of vegetation. The information presented here will serve as a basis for further vegetation studies to be conducted in spring 1988 and for wildlife habitat characterization.

\section{APPROACH}

Landsat and aircraft imagery was used to locate areas of homogeneous vegetation. Field reconnaissance using fixed-wing aircraft and ground vehicles was used to identify the major vegetation types located from the imagery. Large areas of homogeneous vegetation were designated as reference areas and recorded on topographic maps. These reference areas were used to classify Landsat imagery of the entire expansion area to produce a preliminary map of the major vegetation types.

\section{METHODS}

Several data sources were used to produce the preliminary classification. These included:

1. Landsat 5 Thematic Mapper Multispectral Scenes from May 8, 1976, and October 22,1986.

2. Topographic Maps:

\begin{tabular}{lllll}
\multicolumn{1}{c}{$\begin{array}{c}\text { Name } \\
\text { Badger Pocket }\end{array}$} & Sheet & Series & Edition & DMA Stock $^{\#}$ \\
Boylston & 1977 IV & V 791 & 4-DMATC & V791X 19774 \\
Beverly & 1977 I & V 791 & 4-DMATC & V791X 19771 \\
$\begin{array}{c}\text { Yakima Firing } \\
\text { Center }\end{array}$ & $\begin{array}{c}\text { Special } \\
\text { Map }\end{array}$ & V791 & 4-DMATC & V791X 20774 \\
& M & & 4-DMA- & V7915YAKFIRCEN \\
& & & FCSM &
\end{tabular}


3. Video Tape:

- 8-mm digital format taken from a fixed-wing aircraft on October 21,1987

- VHS from an Army helicopter overflight in October 1986.

4. Large format color infrared photography taken by EG\&G, Inc., during the first week of May 1987 at an altitude of $10,000 \mathrm{ft}$.

5. Ground surveys of the proposed acquisition areas conducted on the following dates:

- October 28, 1987

- November 4, 1987

- November 19, 1987

Supervised classification of the Landsat TM scene of October 22, 1986, was conducted to determine the relative distribution of the major vegetation types on the proposed acquisition area. The ground reference areas were used to train the Landsat data using the software "TRAIN" developed at PNL. The trained data were classified with the $\mathrm{I}^{2} \mathrm{~S} 600$ software. The following training classes were used:

1. "Rigida" - This class consists of stiff sage (Artemisia rigida) as the dominant plant species. Sandberg's bluegrass (Poa sandbergii) is the dominant grass species. Buckwheat (Eriogonum spp.) is common. Vegetation cover is sparse and the soil is rocky. This vegetation type is found primarily on the broad ridges north of the Saddle Mountains.

2. "Cheatgrass" - Cheatgrass areas are found primarily at disturbed sites.

Vegetation in this class is predominantly cheatgrass (Bromus tectorum), but other annual weeds, such as tumble mustard (Sissymbrium altissimum) and prickly lettuce (Lactuca sp.), are also found. The vegetation canopy cover is typically $100 \%$. Soil types vary.

3. "Rock" - Rock outcrops and talus slopes are included in this class. 
4. "Big Sage" - This class is found on upland soils, which are usually silty. The dominant species are big sage sagebrush (Artemisia tridentata) and bluebunch wheatgrass (Agropyron spicatum), with Sandberg's bluegrass in association.

5. "Ridge" - This class is found on ridge crests along the slopes of the Saddle Mountains. Because of the steep slopes, shaded and sunny areas are prominent and produce spectral differences on the Landsat imagery. For this reason, two subclasses were produced during the classification: "Ridge Sunny" and "Ridge Shaded." These classes were combined in the preliminary map. The vegetation consists of many species; the dominants include stiff sage, buckwheat, and Sandberg's bluegrass. The soils are rocky with large areas of exposed basalt.

6. "Sagebrush - Bluegrass" - This class is found on silty soils in upland areas. These areas are grazed. The dominant plant species are sagebrush and Sandberg's bluegrass. Bluebunch wheatgrass is often found growing within the canopies of sagebrush where it is protected from grazing. Bare ground is prominent.

7. "Sage Bottom" - This class is found along stream bottoms in Johnson and Middle Canyons. Big sage is the dominant plant. Willows (Salix spp.) and wild roses (Rosa spp.) are found near surface water. Cottonwood (Populus spp.) and aspen (Populus tremuloides) trees are at higher elevations.

8. "Sage - Rigida" - This class, intermediate between "Big Sage" and "Rigida," is found in transition areas between the two. Big sage and stiff sage are approximately equal in abundance. Bluebunch wheatgrass and Sandberg's bluegrass are also abundant. Saddles of ridges commonly have this type of vegetation.

9. "Agricultural Land" - This class included orchards and field crops. Riparian areas in the canyon bottoms are also included.

10. "Water" - This class is primarily the Columbia River. 
11. "Lawn" - This class includes areas surrounding residential areas east of the Columbia River and west of the proposed expansion area.

12. "Sand/Bare Soil" - This class is primarily dune areas.

\section{PRELIMINARY RESULTS}

The above data were used to delineate the relative distribution of major vegetation types within the proposed acquisition area. The vegetation distribution data are presented in map form (Figure 2), but the map was not validated with respect to actual species composition and cover. The distribution data will, however, be useful in identifying the primary habitats for bird and mammal species under consideration for this project.

The supervised classification produced seven readily discernable land cover classes (Table 1). Several of the training classes were not distinguishable spectrally, and consequently, the resulting land cover classes were reduced from the training set. The following training classes were combined to form the land cover classes given in the table:

- "Sand/Bare Soil" and "Rigida" into "Stiff Sage"

- "Sage Bottom," "Ridge Shaded," and "Big Sage" into "Big Sage"

- "Sagebrush-Bluegrass" and "Ridge Sunny" into "Sandberg's Bluegrass"

- "Agricultural Land" and "Lawn" into "Riparian"

\section{WORK REMAINING}

Vegetation distribution information will be used to locate reference sites that will be used for collecting field characterization data on vegetation and soils in spring 1988. The field data will be used to refine and validate the vegetation map. The vegetation/land cover map, once validated, will form a primary data layer in the YFC geographical modeling and analysis package (GRASS) developed by the U.S. Army Construction Engineering Research Laboratory for use by environmental planners 




FIGURE 2. Vegetation Distribution on the Expansion Area. Note that Sandberg's Bluegrass is $50-75 \%$ of the expansion area and Big Sage is $20-30 \%$. Stiff Sage, on the uplands just west of the Columbia River, is $5-15 \%$ of the area; Cheatgrass is $<5 \%$; Bare Rock and Riparian are $<1 \%$ (see Table 1). 

TABLE 1. Land Cover Classes of the Proposed Expansion Area

Land Cover Class

1. Water

2. Cheatgrass

3. Big Sage

4. Stiff Sage

5. Riparian

6. Sandberg's

Bluegrass
Description

Columbia River

Abandoned farmland and disturbed areas

Uplands and canyon bottoms dominated by big sage; bluebunch wheatgrass common; generally silty, deep soils

Uplands with thin rocky soils; stiff sage and wild buckwheat are dominant shrubs; Sandberg's bluegrass common; much bare soil

Moist canyon bottoms; willows, wild roses cottonwoods, rhizomatous grasses common

Broad classification, found on uplands;

$50-75 \%$ consists of areas with sparse vegetation; grasses primarily Sandberg's bluegrass, but bluebunch wheatgrass present in some areas; shrubs primarily small-statured big sage, but stiff sage and wild buckwheat common; soils generally thin

Coverage $^{(a)}$

NA

$<5 \%$

$20-30 \%$

$5-15 \%$

Rock outcrops and talus of primarily basalt $\quad<1 \%$

7. Rock

(a) NA = Not applicable. Coverage refers to the percent of land in the proposed expansion area covered by the respective land cover classes. These values were calculated from pixel counts from the classified Landsat image. 
and resource managers on army installations. This data set will be used in defining critical habitat for plant, bird, and mammal species of interest in the expansion area. In addition, the vegetation map will provide baseline data from which management plans can be developed, and with which monitoring data can be compared. 


\section{WILDLIFE SURVEYS}

The objective of the wildlife task is to determine through field surveys which wildlife species are present on the proposed expansion areas of the Yakima Fining Center. Emphasis during these surveys is being placed on those species of special interest to state and federal agencies. These species include: 1) all wildlife likely to occur in the region that were classified as threatened or endangered by the U.S. Fish

and Wildlife Service or the Washington Department of Wildlife; 2) game species; and 3) many nongame species listed as "special animal species" by the Washington Department of Wildlife (Appendix A, Table A.1). "Special animal species" are animals for which little information exists within the state and that may be rare enough to become classified as threatened or endangered. Although emphasis during the field surveys is being placed on determining the presence or absence of wildlife species, information on abundance is collected whenever possible.

Data included in this report were collected from mid-October 1987 through midJanuary 1988. Additional information will be collected during the spring and summer of 1988 on such topics as wildlife nesting sites, brood rearing sites, breeding sites, and the presence or absence of species that are only seasonally resident on the proposed expansion areas.

\section{RAPTORS}

The objectives of this survey are to 1) identify the species of raptors using the proposed expansion areas; 2 ) identify nest site locations; and 3) document bald eagle (Haliaeetus leucocephalus) use of the Priest Rapids Pool of the Columbia River. Field surveys of wintering raptor populations on the northern expansion area and the bald eagle population on the Priest Rapids Pool have been conducted. Fieldwork on identifying raptor nest site locations will begin in spring 1988 .

\section{Methods}

Surveys of wintering raptors on the proposed northern expansion area were conducted from vehicles. Raptors observed were identified as to species and their locations recorded.

Surveys of bald eagles were conducted during waterfowl surveys from a Cessna 172 flown at approximately 30 to $70 \mathrm{~m}$ above the Priest Rapids Pool. In addition to the 1987-88 survey results, data on wintering bald eagle populations on 
the Priest Rapids Pool for 1986-87 were obtained from S. A. Eisner (University of Montana, Missoula) and summarized. The age (adult or juvenile) of each eagle observed and its location were recorded.

Chi-square analyses were used to determine whether bald eagles disproportionately used the proposed crossing areas relative to the remainder of the Pool. The expected number of bald eagles for the northern, southern, and noncrossing areas was estimated by multiplying the total number of bald eagles observed on the Pool by the proportional length of the Pool for each of the three areas of concern (southern, northern, and noncrossing areas).

\section{$\underline{\text { Results }}$}

Nine species of wintering raptors were observed on the proposed expansion area north of the YFC (Appendix A, Table A.2). Red-tailed hawks (Buteo jamaicensis) and American kestrels (Falco sparverius) were the most frequently sighted species. Two species of raptors of special interest (Appendix A, Table A.1), the golden eagle (Aquila chrysaetos) and the prairie falcon (Falco mexicanus), were observed on the proposed expansion area.

Bald eagles were observed throughout the Priest Rapids Pool (Figure 3), where they feed on wintering waterfowl and salmon carcasses. The numbers of bald eagles observed during the winters of 1986-87 and 1987-88 in the proposed northern, southern, and noncrossing areas were 18,18 , and 114 , respectively. The numbers expected to be seen in these three major river segments, based on the assumption that bald eagles were distributed in proportion to area, were 15, 20, and 115, respectively. The difference between observed and expected numbers of bald eagles was not significant ( $x^{2}=0.81, P=0.67$ ), indicating that the proposed crossing areas did not harbor a disproportionate number of eagles.

\section{AQUATIC BIRDS}

The objectives of this survey are to 1) identify waterfowl nesting areas on the proposed crossing sites; 2) locate waterfowl brood rearing areas on or near the proposed crossing sites; 3 ) document the number of wintering waterfowl and areas they use on the Priest Rapids Pool; and 4) document the use of Priest Rapids Pool by other aquatic birds of special interest to state and federal agencies (Appendix A, 
Table A.1). The surveys on waterfowl nesting and brood rearing areas will be done during spring 1988. Data were, however, obtained on the distribution of waterfowl for the winter of 1986-87 and for a portion of the winter of 1987-88 (Appendix B).

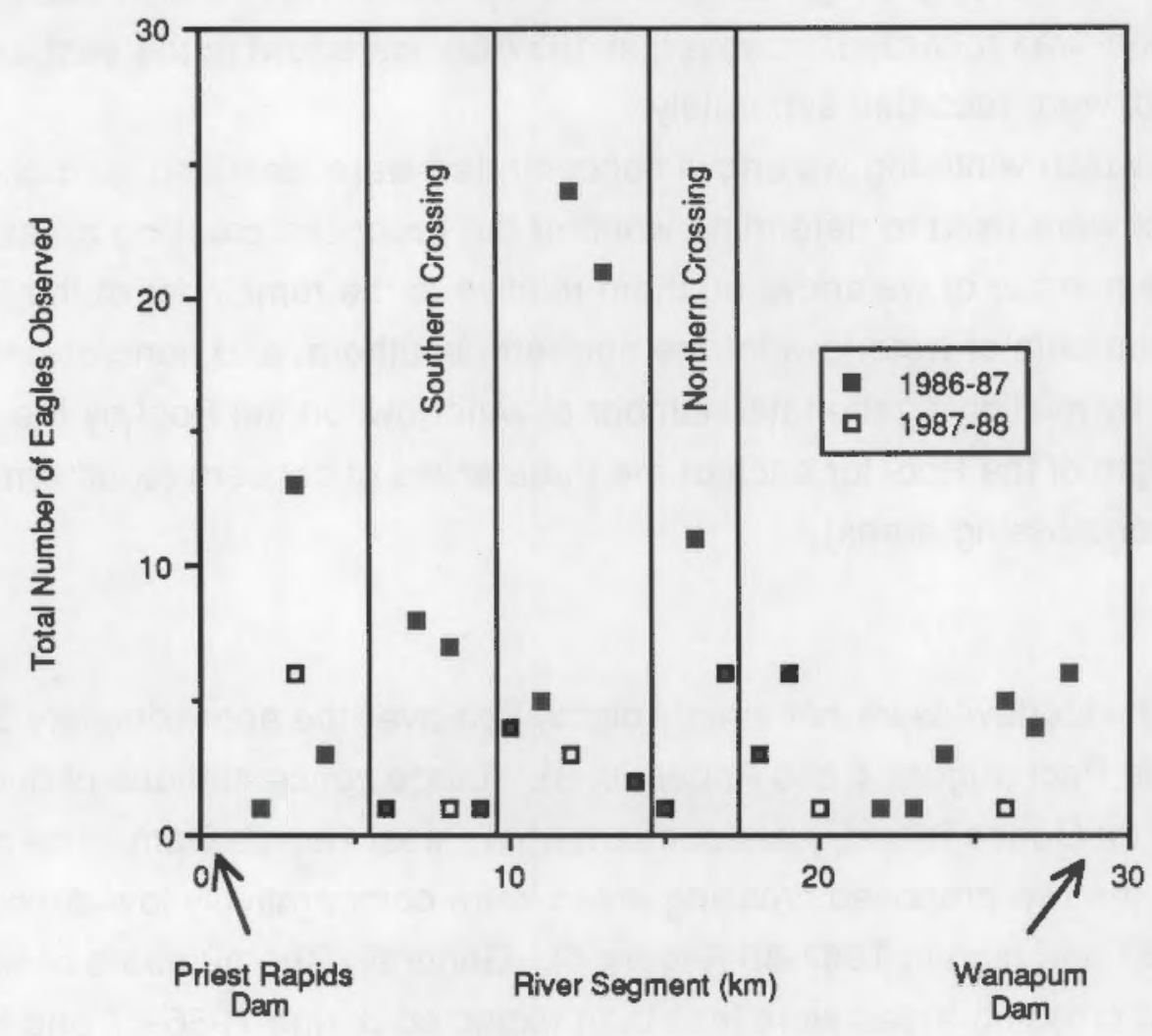

FIGURE 3. Distribution of Bald Eagles During the Winters of 1986-87 and 1987-88 on the Priest Rapids Pool of the Columbia River. Data presented as total number of eagles observed during 27 flights in 1986-87 and three flights in 1987-88. The 1986-87 data were obtained by S. A. Eisner, University of Montana, and the 1987-88 data were obtained by Pacific Northwest Laboratory. 


\section{Methods}

Waterfowl were identified and counted from a Cessna 172 flown at elevations of approximately 30 to $70 \mathrm{~m}$ above the Priest Rapids Pool. During the winter of 1986-87, flights were made at approximately 1 -week intervals from mid-December through midMarch. Approximately two to three flights were made each month from October 1987 to January 1988. Waterfowl observed during the winter of $1986-87$ were classified as coots (Fulica americana), ducks, or geese (Branta canadensis). In 1987-88 waterfowl were identified to species. During both years the number of waterfowl in each $1-\mathrm{km}$ section of the pool was recorded; however, in 1987-88 waterfowl in the east and west sides of the Pool were recorded separately.

Areas in which wintering waterfowl concentrated were identified, and chisquare analyses were used to determine whether the proposed crossing areas had a disproportionate number of waterfowl on them relative to the remainder of the Pool. The expected numbers of waterfowl for the northern, southern, and noncrossing areas were estimated by multiplying the total number of waterfowl on the Pool by the proportional length of the Pool for each of the three areas of concern (southern, northern, and noncrossing areas).

\section{Results}

Wintering waterfowl were not evenly distributed over the approximately $30 \mathrm{~km}$ of the Priest Rapids Pool (Figure 4 and Appendix B). Large concentrations of ducks and geese occurred on Goose Island, just upstream from Priest Rapids Dam. The number of waterfowl on the two proposed crossing areas were comparatively low during the winter of 1986-87 and high in 1987-88 (Figure 4). Generally, the numbers of waterfowl on the proposed crossing areas were less than expected during 1986-87 and higher than expected during 1987-88 (Appendix A, Table A.3), based on the assumption of equal distribution of birds along the entire Pool. It is unknown why there was a change in distribution of wintering waterfowl on the Pool between 1986-87 and 1987-88.

Seasonally, the numbers of waterfowl were highest in December and lowest in March. This seasonal decrease in the number of waterfowl was the same for the proposed crossing and noncrossing areas (Figure 5). The Priest Rapids Pool was searched during the winter of 1987-88 for two other aquatic bird species of special interest (Appendix A, Table A.1), American white pelicans (Pelecanthus erythrorhynchos) 

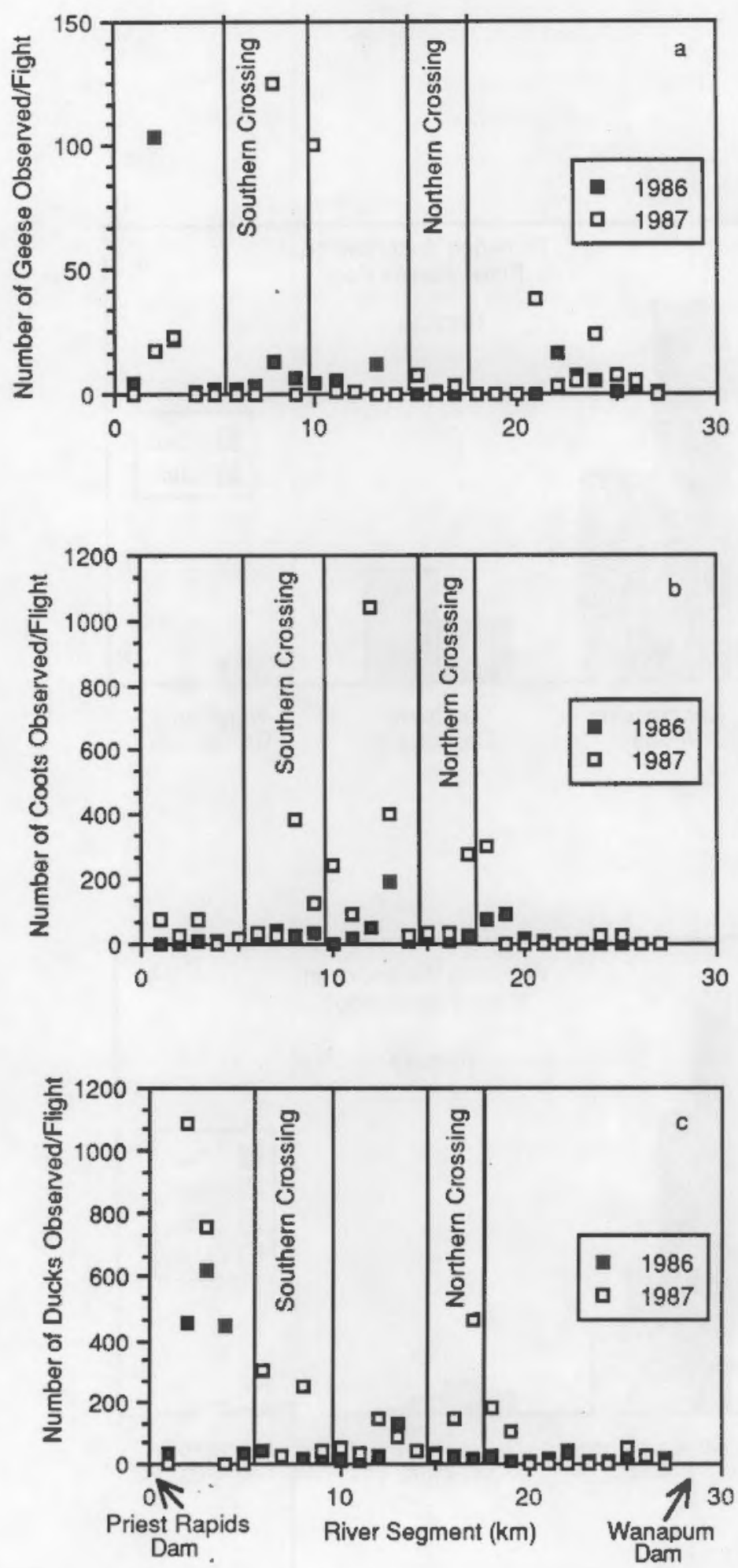

FIGURE 4. The Distribution of Waterfowl on the Priest Rapids Pool of the Columbia River for the Winters of 1986-87 and 1987-88. The 1986-87 data were obtained by S. A. Eisner, University of Montana, and the 1987-88 data were obtained by Pacific Northwest Laboratory. 

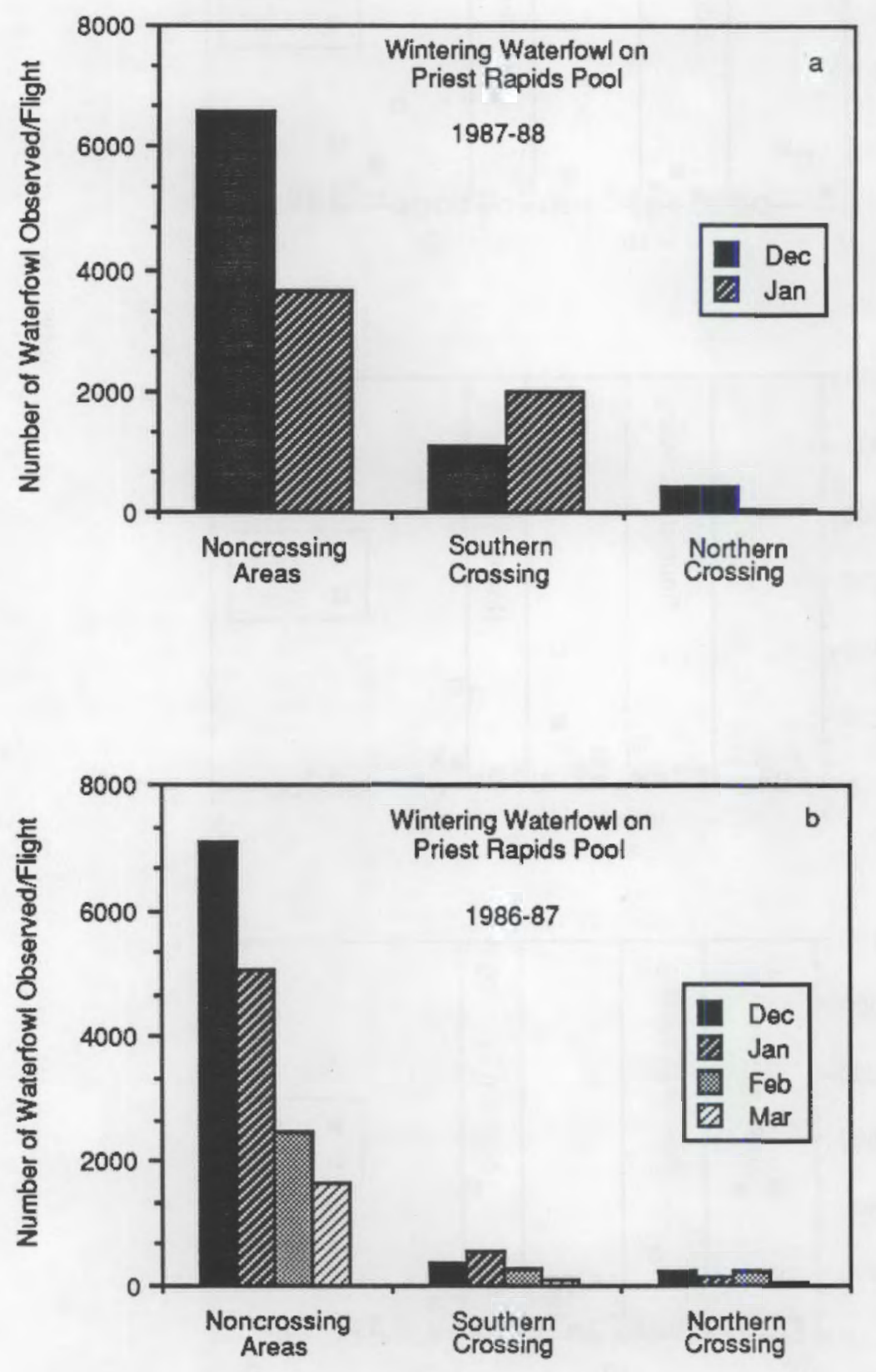

FIGURE 5. The Seasonal Distribution of Waterfowl on the Priest Rapids Pool of the Columbia River for the Winters of 1986-87 and 1987-88. The 1986-87 data were obtained by S. A. Eisner, University of Montana, and the 198788 data were obtained by Pacific Northwest Laboratory. 
and common loons (Gavia immer). No white pelicans were observed on the Pool in December or January. Common loons were observed 13 times during four flights (Figure 6). Loons were observed on two occasions in the southern crossing; none were observed in the northern crossing.

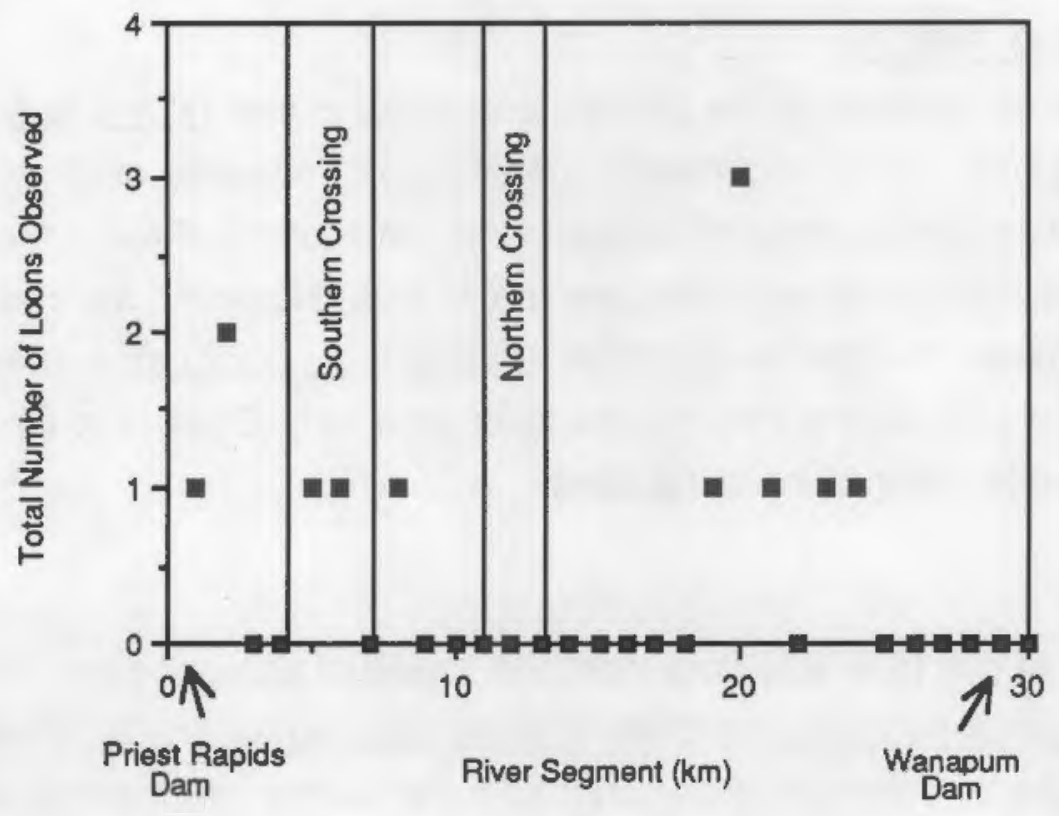

FIGURE 6. The Distribution of Common Loons on the Priest Rapids Pool of the Columbia River. Data are presented as a cumulative total for four flights made during the winter of 1987-88.

\section{UPLAND GAME BIRDS}

The objectives of this survey are to 1) identify the number and locations of sage grouse (Centrocercus urophasianus) leks on the proposed northern expansion area; and 2) document the species of upland game birds that use the proposed expansion area. Field surveys of sage grouse leks will take place in the spring of 1988. Some information, however, has already been collected on the upland game bird species present on the proposed northern expansion area. These data were collected incidental to other surveys.

Sage grouse were observed on three occasions near Boylston (Figure 1 , Universal Transverse Mercator coordinates - 710500, 5199000). Covey size ranged from 2 to 15 birds. Other species of upland game birds observed on the proposed 
northern expansion area included California quail (Callipepla californica), chukars (Alectoris chukar), and gray (Hungarian) partridge (Perdix perdix). California quail occurred primarily in the riparian zones along Johnson Creek and in Middle Canyon (Figure 1). The Hungarian partridge were observed near Boylston, and chukars were observed along the canyon rims of Johnson Creek and Middle Canyon.

\section{OTHER TERRESTRIAL BIRDS}

The objectives of this task are to identify long-billed curlew (Numenius americanus) nesting sites and to document the presence or absence of other terrestrial bird species of special interest (Appendix A, Table A.1). Field surveys for this task will continue through spring and summer of 1988. However, several sightings have already been made of loggerhead shrikes (Lanius ludiovicianus), a species of special interest, in the proposed northern expansion area from October to December 1987 while other studies were being conducted.

\section{LARGE ANIMALS}

The objective of this task is to document the seasonal presence and distribution of mule deer (Odocoileus hemionus) and elk (Cervus elaphus) on the proposed northern expansion area. This task is ongoing; however, some information has been collected during ground surveys from October to December 1987.

Based on tracks and observations, mule deer are present throughout the proposed expansion area from October to December. Subjectively, densities of deer on the area appear to be relatively low in comparison to similar habitats on the nearby Hanford Site.

Elk (two adult cows and one calf) were observed only once, but elk tracks show that they are in the Johnson Creek and Middle Canyon areas at least from October to December. However, elk calf tracks observed in October indicate that there is a small herd of elk on the proposed northern expansion area all year. Presumably, these calves were born on or near the expansion area. It is unlikely they would have migrated to the expansion area before October. 


\section{FURBEARING ANIMALS}

The objective of this task is to document the presence of animals classed as furbearers [beaver (Castor canadensis), mink (Mustela vison), raccoon (Procyon lotor), muskrat (Ondatra zibethicus), and bobcat (Felis rufus)] on the proposed expansion areas. The only furbearer observed on the expansion area from October to December 1987 were beaver. Two adult beaver and eight beaver ponds were located along a 1- to 2-km segment of Johnson Creek (Universal Transverse Mercator coordinates = $725300,5195600)$. Three beaver lodges and two bank dens were also observed.

\section{SMALL MAMMALS}

The objective of this survey is to document the presence or absence of state or federally protected small mammal species and/or species of special interest on the proposed northern expansion area (Appendix A, Table A.1). Field surveys of bats and rabbits will be conducted in the spring and summer of 1988 . Field surveys of mice began in October 1987; preliminary results are reported here.

\section{Methods}

Species composition and distribution of mice on the proposed northern expansion area were evaluated using pitfall and live traps. The traps were placed along 14 assessment lines, each of which consisted of 20 trapping stations located at $10-\mathrm{m}$ intervals. At each station two Sherman live traps were placed, for a total of 40 live traps/assessment line. In addition, pitfall traps, consisting of 2.5-L cans buried flush with ground level, were placed at 10 of the trapping stations. Live traps were baited with a mixture of rolled oats, peanut butter, bacon grease, and bird seed. Traps were run for two consecutive nights with no prebaiting and checked daily for mice. All captured mice were released, except for three retained as voucher specimens.

\section{Results}

Fourteen small-mammal assessment trap lines were run for a total of 1,260 trapnights (live traps and pitfalls). Assessment lines were located in all of the major habitat types on the proposed northern expansion area (Appendix A, Table A.4). Twohundred and fifty-four individuals of six different small mammal species were captured (Appendix A, Table A.5) for an overall trapping success of 0.20 captures/trap-night. 
The capture rate and species composition were comparable to those reported for similar habitat types (Rickard 1960, O'Farrell 1975).

Only one species of special interest to state and federal agencies, the sagebrush vole (Lemmiscus curtatus), was captured. This species was captured in most of the habitats sampled on the proposed expansion area (Appendix A, Tables A.4 and A.5). Capture frequency, a crude index of abundance, for this species on the proposed expansion area was comparable to that reported elsewhere (Mullican and Keller 1986).

\section{SUMMARY OF WILDLIFE SURVEYS}

From October 1987 through January 1988, 13 wildlife species of special interest, in addition to waterfowl, were observed on the proposed expansion areas (Table 2). Additional surveys are planned during the spring and summer of 1988 to further characterize the wildlife using the proposed expansion areas (Table 3). These surveys will address such topics as wildlife distribution, breeding sites, nesting areas, and rearing locations. 
TABLE 2. Summary of Wildlife Species of Special Interest Observed on the Proposed Expansion Areas to the Yakima Firing Center from October 1987 Through January 1988

\begin{tabular}{l}
\multicolumn{1}{c}{ Species } \\
\hline Birds \\
\hline Bald eagle \\
Golden eagle \\
Prairie falcon \\
Common loon \\
Loggerhead shrik \\
Waterfowl \\
Sage grouse \\
California quail \\
Chukar \\
Gray partridge \\
\\
Mammals \\
Sagebrush vole \\
Mule deer \\
Rocky Mt. elk \\
Beaver
\end{tabular}

\begin{tabular}{ll} 
Status $^{(a)}$ & \multicolumn{1}{c}{ Location Observed } \\
\cline { 2 - 3 } FT & Northern and southern crossings \\
PS & Northern expansion area \\
PM & Northern expansion area \\
PT & Southern river crossing \\
PS & Northern expansion area \\
Game & Northern and southern crossings \\
Game & Northern expansion area \\
Game & Northern expansion area \\
Game & Northern expansion area \\
Game & Northern expansion area
\end{tabular}

(a) FT = Federally Threatened species; PM = state Proposed Monitoring species; Game = state game species; PS = state Proposed Sensitive species; PT = state Proposed Threatened. 
TABLE 3. Wildlife Surveys Planned for the Proposed Expansion Areas to the Yakima Firing Center During the Spring and Summer of 1988

Survevs

Raptors

Identify distribution

Identify nest sites

Aquatic Birds

Identify nest sites

Identify brood rearing areas

Upland Game

Identify sage grouse leks

Other Terrestrial Birds

Identify curlew nesting sites

Identify species of special interest

Large Animals

Document seasonal distribution

Furbearing Animals

Document presence

Small Mammals

Bat surveys

Rabbit surveys

\section{Month}

Feb Mar Apr May Jun Jul Aug Sep
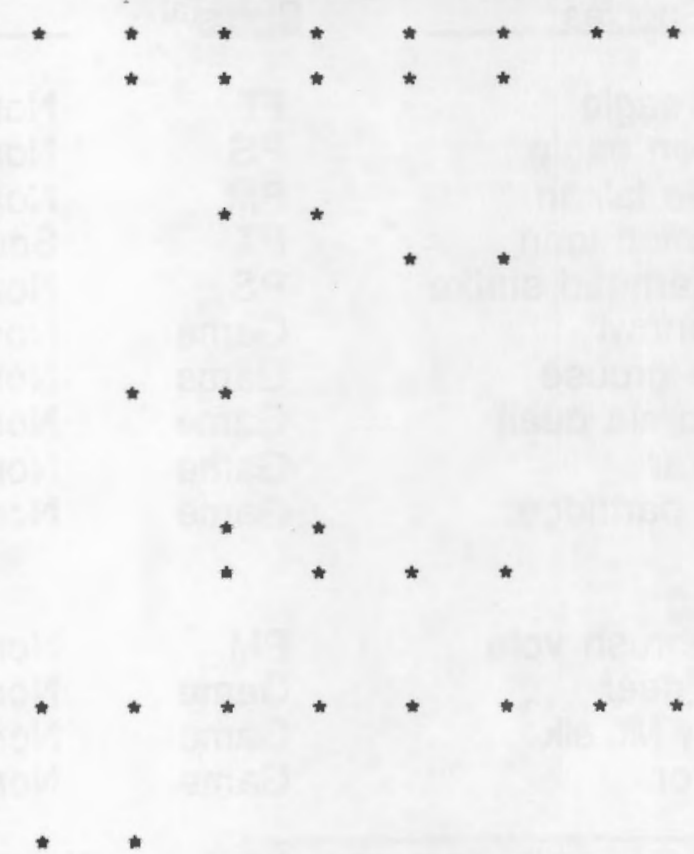


\section{EISHERIES SURVEYS}

Aquatic surveys are being conducted in the proposed northern expansion area and at the proposed Columbia River crossing sites to identify the distribution of game fish and other species of interest. Studies have been conducted from October 30 to November 24, 1987, and are continuing.

\section{NORTHERN EXPANSION AREA STUDIES}

The objective of these surveys is to determine the distribution of anadramous salmonids, resident rainbow trout (Salme gairdneri), and other resident fish that overwinter in the Johnson Creek drainage. Winter stream surveys were restricted to the proposed northern expansion area because of low seasonal flows. Additional surveys are planned to determine the seasonal use of streams that originate in the eastern and northern expansion areas and for those that flow into the east shore of the Columbia River along existing YFC boundaries.

We surveyed the entire length of Johnson Creek and portions of Middle Canyon where surface flows were observed in November 1987 . Fish were mainly collected by using a backpack electroshocker. On several occasions, we blocked the stream channel with a seine (1/8-in. mesh), then electroshocked and dislodged rocks upstream of the net to determine if fish were in the substrate. Water temperatures in areas of flowing water remained constant at $11^{\circ} \mathrm{C}$ through late November. However, isolated pools in the headwaters had up to $5 \mathrm{~cm}$ of ice in mid-November.

Resident rainbow trout were the only fish species collected within the proposed northern expansion area. No fish were collected above a barrier falls, located about $2 \mathrm{~km}$ below the mouth of Foster Creek (Figure 7). Rainbow trout, ranging from 6 to $27 \mathrm{~cm}$ fork length, were abundant from the barrier falls and downstream to the eastern edge of the expansion area. Habitat through the drainage was variable and ranged from bedrock, mud/silt over cobble, to gravel bottom. The upper reach was characterized by deep gulleys and overhanging willows, while the lower reach contained a few beaver ponds, had a shallow streambed, and was choked with cress. Rainbow trout were also collected about $2 \mathrm{~km}$ up the Middle Canyon drainage (Figure 7). The distribution and condition of fish in Middle Canyon appeared restricted by the discontinuous flows and by the general lack of stream cover. No evidence of 


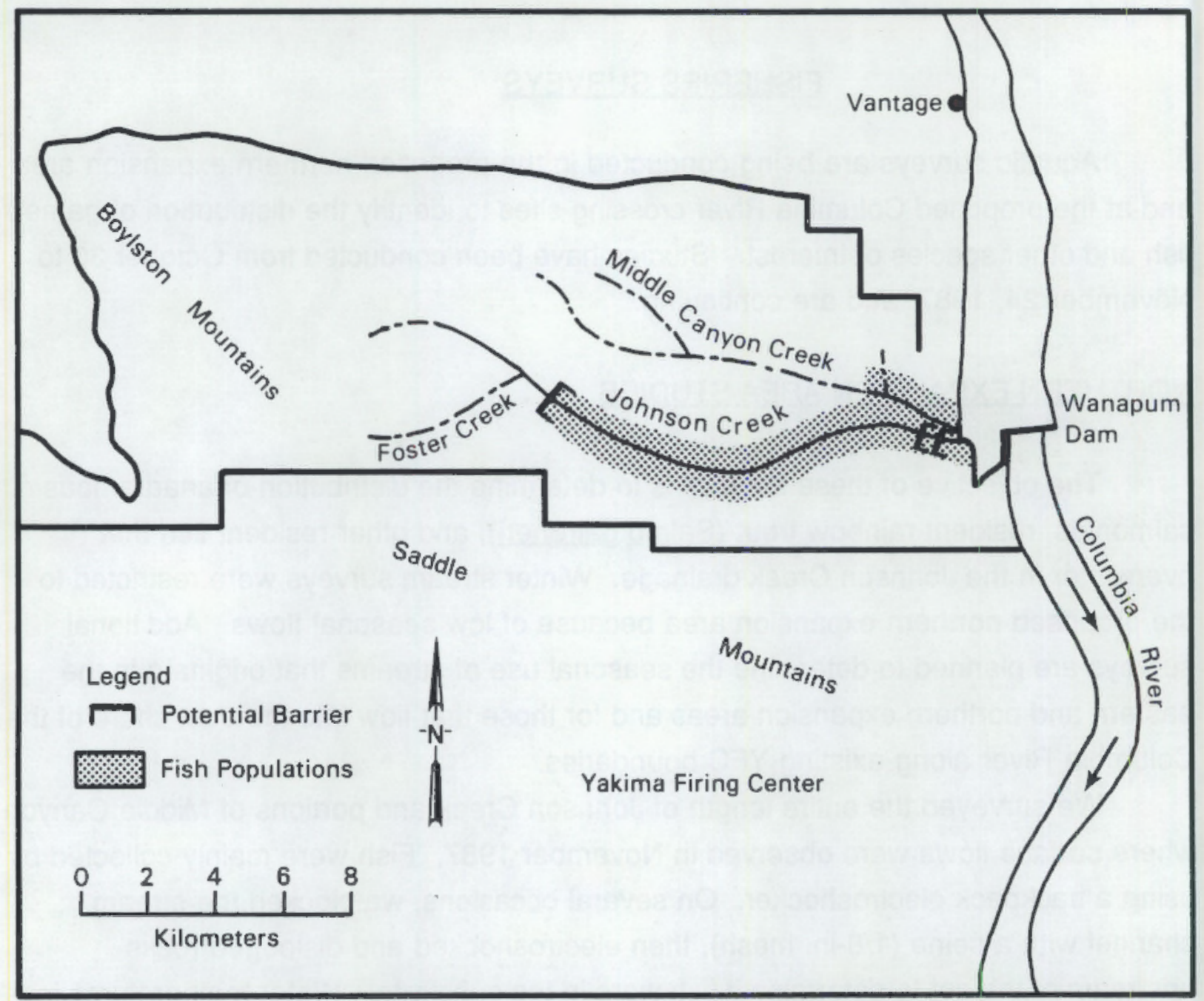

FlGURE 7. The Johnson Creek and Middle Canyon Drainages and Location of Winter Fish Populations. Areas of intermittent flow are indicated by a dashed line. 
anadramous salmonids was found in surveys of the lower reaches of the Johnson Creek and Middle Canyon drainages within the proposed expansion area.

Additional surveys were conducted in lower Johnson Creek on private land outside the proposed northern expansion area. We collected adult prickley sculpin (Cottus asper), three-spine stickleback (Gasterosteus aculeatus), juvenile largescale sucker (Catostomus macrocheilus), and redside shiner (Richardsonius balteatus) near the confluence of Johnson Creek and the Columbia River. The rainbow trout in this section were smaller than those collected upstream and ranged from 6 to $17 \mathrm{~cm}$. Although adult fall chinook salmon and steelhead occur in the Columbia River near the mouth of Johnson Creek, no adult salmonids were observed in the creek. A beaver dam and small falls may prevent anadramous fish passage in lower Johnson Creek.

\section{COLUMBIA RIVER CROSSING SITE}

The objective of these surveys is to determine the distribution of fall chinook salmon spawning in the vicinity of the proposed niver crossing areas. Adult steelhead trout migrate through this portion of the Columbia River, but no other anadramous fish use is anticipated for these locations in the winter. Additional surveys are planned to determine the seasonal occurrence and use of the river crossing sites and the lower reaches of Hanson Creek by resident and anadramous fish.

Low elevation aerial surveys were conducted on October 31, November 7, and November 15,1987 . These times were selected to coincide with peak spawning activity of fall chinook salmon in the Hanford Reach of the Columbia River. There was no evidence of fall chinook salmon spawning activity near the two river crossing areas (river miles 405 and 409). Both locations are within the influence of the Priest Rapids Pool and flows appeared unsuitable for spawning. The nearest upstream spawning of salmon was observed at river miles 413 to 414 . Approximately 400 salmon redds were observed, with most spawning occurring just below Wanapum Dam. Surveys will be conducted to determine the use of downstream areas by juveniles that emerge from these redds. 


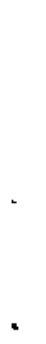




\section{REFERENCES}

Mullican, T. R., and B. L. Keller. 1986. "Ecology of the Sagebrush Vole (Lemmiscus curtatus) in Southeastern Idaho." Canadian J. Zool. 64(6):1218-1223.

O'Farrell, T. P. 1975. "Seasonal and Altitudinal Variations in Populations of Small Mammals on Rattlesnake Mountain, Washington." Amer. Midl. Nat. 94(1):190-204.

Rickard, W. H. 1960. "The Distribution of Small Mammals in Relation to the Climax Vegetation Mosaic in Eastern Washington and Northern Idaho." Ecology 41(1) 99106. 


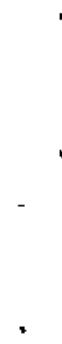




\section{APPENDIX A}

\section{WILDLIFE SURVEY DATA TABLES}




\section{APPENDIX A}

\section{WILDLIFE SURVEY DATA TABLES}

IABLEA.1. Wildlife Species That Received Special Emphasis During Field Surveys on the Proposed Expansion Areas to the Yakima Firing Center

\begin{tabular}{l} 
Species \\
\hline Birds \\
\hline Bald eagle \\
(Haliaeetus leucocephalus) \\
Golden eagle \\
(Aquila chrysaetos) \\
Peregrine falcon \\
(Falco perearinus) \\
Prairie falcon \\
(Falce mexicanus) \\
Gyrfalcon \\
(Falco rusticolus) \\
Swainson's hawk \\
(Buteo swainsoni) \\
Ferruginous hawk \\
(Buteo regalis) \\
Northern goshawk \\
(Accipiter gentilis) \\
Burrowing owl \\
(Athene cunicularia) \\
American white pelican \\
(Pelecanus erythrorhynchos) \\
Sandhill crane \\
(Grus canadensis) \\
Common loon \\
(Gavia immer) \\
Long-billed curlew \\
(Numenius americanus) \\
Loggerhead shrike \\
(Lanius ludovicianus) \\
Sage thrasher \\
(Oreoscoptes montanus) \\
Sage sparrow \\
(Amphispiza belli) \\
Purple martin \\
(Progne subis)
\end{tabular}


TABLEA.1. (contd)

Western bluebird

(Sialia mexicana)

Ducks and geese

Sage grouse

(Centrocercus urophasianus)

Other upland game birds

Special animal species - PS

Game species

Game species

Game species

Mammals

Pygmy rabbit

(Sylvilagus idahoensis)

Yuma myotis

(Myotis yumanensis)

Long-eared myotis

(Myotis evotis)

Western pipistrelle

(Pipistrellus hesperus)

Pallid bat

(Antrozous pallidus)

Townsend's big-eared bat

(Plecotus townsendii)

Sagebrush vole

(Lemmiscus curtatus)

Merriam's shrew

(Sorex merriami)

Rocky Mountain elk

(Cervus elaphus)

Mule deer

(Odocoileus hemionus)

Furbearers

Threatened (state)

Special animal species - PM

Special animal species - PM

Special animal species - PM

Special animal species - PM

Special animal species - PT

Special animal species - PM

Special animal species - PS

Game species

Game species

Game species

(a) PM = Proposed Monitor species; PS = Proposed Sensitive species; PT = Proposed Threatened species. 
IABLEA.2. Sightings of Raptors on the Proposed Northern Expansion Area to the Yakima Firing Center from October to December 1987.

Species Observed
Sharp-shinned hawk
(Accipiter striatus)
Red-tailed hawk
(Buteo jamaicensis)

Rough-legged hawk (Buteo lagopus)

Golden eagle (Aquila chrysaetos)

American kestrel (Falco sparverius)

Prairie falcon (Ealco mexicanus)

Northern harrier (Circus cyaneus)

Great horned owl (Bubo virginianus)

Long-eared owl (Asio otus)
Number Observed

\begin{tabular}{ccc}
\hline October & $\frac{\text { November }}{1}$ & December \\
9 & 3 & \\
& 2 & \\
1 & 1 & 2 \\
6 & 8 & \\
2 & & \\
1 & 2 & \\
1 & & \\
1 & 1 &
\end{tabular}


IABLEA.3. Distribution of Wintering Waterfowl on the Priest Rapids Pool of the Columbia River During the Winters of 1986-87 and 1987-88 Relative to the Proposed Crossing Sites. Data are presented as number observed/census flight.

$1986-87$

Observed Ducks

Expected Ducks

Observed Geese

Expected Geese

Observed Coots

Expected Coots

\section{7-88}

Observed Ducks

Expected Ducks

Observed Geese

Expected Geese

Observed Coots

Expected Coots

$\frac{\text { Location on Pool }}{\text { Northern }} \frac{\text { Southern Noncrossing }}{}$

Crossing

Crossing

112

291

2002

$1679 \quad 265<0.001$

22

24

191

166

$23<0.001$

56

68

116

90

505

519

$10 \quad 0.007$

630

384

621

513

2594

$2948 \quad 221<0.001$

11

36

125

225

277

$152<0.001$

338

576

2345

434

2497

$56<0.001$ 
TABLEA.4. Habitat Training Classes Trapped for Small Mammals During OctoberDecember 1987 on the Proposed Northern Expansion Area to the Yakima Firing Center

\begin{tabular}{|c|c|c|c|}
\hline $\begin{array}{l}\text { Line } \\
\text { No. }\end{array}$ & Dates Trapped & Habitat Type & Descriptive Comments \\
\hline 1 & $10 / 28-10 / 30$ & Sage bottom & Riparian sage \\
\hline 2 & $10 / 28-10 / 30$ & Sage Bottom & Hillside seep area \\
\hline 3 & $11 / 3-11 / 5$ & Ridge & Steep slope \\
\hline 4 & $11 / 3-11 / 5$ & Sage-rigida & Ridge top \\
\hline 5 & $11 / 3-11 / 5$ & Sage-bluegrass & Flats \\
\hline 6 & $11 / 11-11 / 13$ & Rigida & Ridge top \\
\hline 7 & $11 / 11-11 / 13$ & Sage bottom & Bottom of small draw \\
\hline 8 & $11 / 11-11 / 13$ & Sage bottom & Bottom of draw \\
\hline 9 & $11 / 11-11 / 13$ & Rigida & Heavily grazed ridge top \\
\hline 10 & $11 / 16-11 / 18$ & Sage bottom & Riparian \\
\hline 11 & $11 / 16-11 / 18$ & Disturbed & Disturbed farmstead \\
\hline 12 & $12 / 8-12 / 10$ & Ridge & Ridge top, little sage \\
\hline 13 & $12 / 8-12 / 10$ & Rigida & Steep hillside \\
\hline 14 & $12 / 8-12 / 10$ & Big Sage & Bottom of draw \\
\hline
\end{tabular}

IABLEA.5. Summary of Small Mammal Trapping Results for October-December 1987 on the Proposed Northern Expansion Area to the Yakima Fining Center
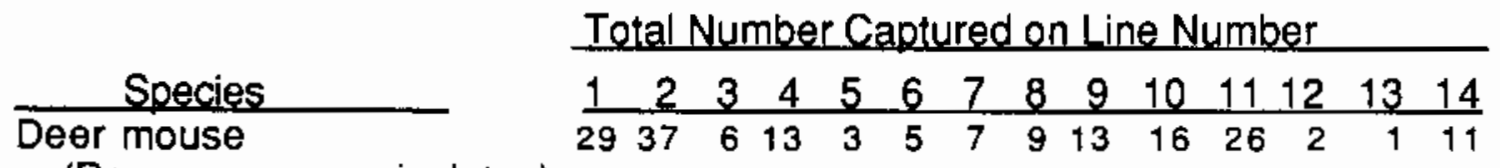

(Peromyscus maniculatus)

\begin{tabular}{|c|c|c|c|c|c|c|}
\hline $\begin{array}{l}\text { Sagebrush vole } \\
\text { (Lemmiscus curtatus) }\end{array}$ & 2 & & 3 & & 2 & \\
\hline $\begin{array}{l}\text { Long-tailed vole } \\
\text { (Microtus longicaudus) }\end{array}$ & & 2 & & & & \\
\hline $\begin{array}{l}\text { Montane vole } \\
\text { (Microtus montanus) }\end{array}$ & & 2 & & & & \\
\hline $\begin{array}{l}\text { Pocket mouse } \\
\text { (Peroanathus parvus) }\end{array}$ & 6 & 2 & 4 & 1 & 3 & 2 \\
\hline $\begin{array}{l}\text { Least chipmunk } \\
\quad \text { (Eutamias minimus) }\end{array}$ & 11 & 5 & & & 6 & \\
\hline
\end{tabular}




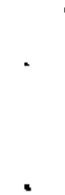




\section{APPENDIX B}

NUMBERS OF WATERFOWL OBSERVED

ON THE PRIEST RAPIDS POOL OF THE COLUMBIA RIVER

DURING THE WINTERS OF 1986-87 AND 1987-88 


\section{APPENDIX B}

NUMBERS OF WATERFOWLOBSERVED QN THE PRIEST RAPIDS POOL OF THE COLUMBIA RIVER DURING THE WINTERS OF 1986-87( ${ }^{\text {(a) }}$ AND 1987-88

TABLEB.1. Ducks Observed in 1986-87

\begin{tabular}{|c|c|c|c|c|}
\hline River & & umberc & $\frac{986-87}{5(h)}$ & \\
\hline Segment ( $\mathrm{km}$ ) & $\mathrm{Dec}(\mathrm{b})$ & $\operatorname{Jan}^{(b)}$ & $\mathrm{Feb}^{(\mathrm{b})}$ & $\frac{\operatorname{Mar}{ }^{(b)}}{50}$ \\
\hline $0-1$ & 300 & 245 & 9 & 53 \\
\hline $1-2$ & 0 & 4435 & 1800 & 1540 \\
\hline $2-3$ & 200 & 6250 & 1260 & 1100 \\
\hline $3-4$ & 3160 & 4280 & 75 & 60 \\
\hline $4-5$ & 510 & 70 & 0 & 35 \\
\hline $5-6$ & 542 & 140 & 0 & 25 \\
\hline $6-7$ & 13 & 335 & 2 & 83 \\
\hline $7-8$ & 105 & 160 & 32 & 60 \\
\hline $8-9$ & 118 & 175 & 65 & 42 \\
\hline $9-10$ & 46 & 40 & 45 & 82 \\
\hline $10-11$ & 20 & 120 & 30 & 45 \\
\hline $11-12$ & 180 & 225 & 0 & 20 \\
\hline $12-13$ & 745 & 487 & 790 & 150 \\
\hline $13-14$ & 17 & 24 & 285 & 340 \\
\hline $14-15$ & 45 & 410 & 62 & 60 \\
\hline $15-16$ & 196 & 97 & 150 & 26 \\
\hline $16-17$ & 173 & 40 & 14 & 20 \\
\hline $17-18$ & 155 & 70 & 10 & 185 \\
\hline $18-19$ & 14 & 30 & 5 & 50 \\
\hline $19-20$ & 10 & 110 & 40 & 0 \\
\hline $20-21$ & 5 & 110 & 150 & 0 \\
\hline $21-22$ & 30 & 220 & 414 & 25 \\
\hline $22-23$ & 5 & 60 & 30 & 6 \\
\hline $23-24$ & 40 & 152 & 0 & 2 \\
\hline $24-25$ & 149 & 293 & 20 & 0 \\
\hline $25-26$ & 97 & 208 & 34 & 18 \\
\hline $26-27$ & 110 & 99 & 24 & 4 \\
\hline $27-28$ & 30 & 10 & 20 & 2 \\
\hline
\end{tabular}

\footnotetext{
(a) The data for 1986-87 were obtained by S. A. Eisner, University of Montana, Missoula.

(b) Cumulative total for three flights in December, five in January, four in February, and five in March.
} 
IABLE B.2. Geese Observed in 1986-87

\begin{tabular}{|c|c|c|c|c|}
\hline River & & mberc & $1986-87$ & \\
\hline Segment (km) & $\operatorname{Dec}(a)$ & $\operatorname{Jan}^{(a)}$ & $\mathrm{Feb}^{(a)}$ & Marra) \\
\hline $0-1$ & & 50 & 15 & 0 \\
\hline $1-2$ & 0 & 40 & 953 & 765 \\
\hline $2-3$ & 0 & 20 & 102 & 250 \\
\hline $3-4$ & 0 & 2 & 12 & 0 \\
\hline $4-5$ & 0 & 30 & 0 & 0 \\
\hline $5-6$ & 0 & 40 & 0 & 0 \\
\hline $6-7$ & 0 & 50 & 0 & 0 \\
\hline $7-8$ & 0 & 175 & 20 & 20 \\
\hline $8-9$ & 0 & 25 & 32 & 48 \\
\hline $9-10$ & 7 & 0 & 35 & 35 \\
\hline $10-11$ & 0 & 100 & 0 & 0 \\
\hline $11-12$ & 0 & 0 & 20 & 0 \\
\hline $12-13$ & 0 & 30 & 75 & 100 \\
\hline $13-14$ & 0 & 0 & 0 & 0 \\
\hline $14-15$ & 0 & 7 & 2 & 0 \\
\hline $15-16$ & 0 & 15 & 0 & 0 \\
\hline $16-17$ & 0 & 0 & 0 & 4 \\
\hline $17-18$ & 0 & 0 & 0 & 0 \\
\hline $18-19$ & 0 & 0 & 0 & 0 \\
\hline $19-20$ & 5 & 0 & 0 & 0 \\
\hline $20-21$ & 0 & 0 & 0 & 0 \\
\hline $21-22$ & 270 & 0 & 2 & 0 \\
\hline $22-23$ & 0 & 90 & 31 & 12 \\
\hline $23-24$ & 11 & 50 & 9 & 25 \\
\hline $24-25$ & 0 & 0 & 15 & 0 \\
\hline $25-26$ & 0 & 25 & 10 & 13 \\
\hline $26-27$ & 0 & 0 & 27 & 0 \\
\hline
\end{tabular}

(a) Cumulative total for 3 flights in December, five in January, four in February, and five in March. 
IABLEB.3. Coots Observed in 1986-87

River

Segment $(\mathrm{km})$

$0-1$

$1-2$

2-3

3-4

4-5

5-6

6-7

$7-8$

8-9

9-10

10-11

11-12

12-13

13-14

14-15

15-16

16-17

17-18

$18-19$

$19-20$

20-21

21-22

22-23

23-24

24-25

25-26

26-27

27-28
Number of Coots. 1986-87

\begin{tabular}{|c|c|c|c|}
\hline$\overline{D_{e c}(a)}$ & $\operatorname{Jan}^{(a)}$ & $\operatorname{Eeb}^{(a)}$ & Marí \\
\hline & 50 & 0 & 0 \\
\hline 0 & 0 & 50 & 0 \\
\hline 0 & 20 & 100 & 50 \\
\hline 0 & 135 & 20 & 0 \\
\hline 0 & 305 & 40 & 0 \\
\hline 0 & 330 & 15 & 17 \\
\hline 135 & 180 & 380 & 0 \\
\hline 65 & 200 & 95 & 0 \\
\hline 100 & 70 & 366 & 20 \\
\hline 0 & 0 & 0 & 0 \\
\hline 20 & 130 & 110 & 0 \\
\hline 163 & 185 & 550 & 6 \\
\hline 850 & 1090 & 1300 & 90 \\
\hline 16 & 0 & 0 & 70 \\
\hline 60 & 130 & 182 & 0 \\
\hline 0 & 10 & 100 & 50 \\
\hline 0 & 0 & 320 & 105 \\
\hline 0 & 60 & 300 & 925 \\
\hline 0 & 200 & 700 & 600 \\
\hline 0 & 0 & 250 & 20 \\
\hline 0 & 5 & 150 & \\
\hline 0 & 0 & 0 & \\
\hline 0 & 10 & 0 & \\
\hline 0 & 0 & 10 & \\
\hline 0 & 0 & 0 & \\
\hline 0 & 0 & 0 & \\
\hline 0 & 0 & 0 & \\
\hline 0 & 0 & 0 & \\
\hline
\end{tabular}

(a) Cumulative total for three flights in December, five in January, four in February, and five in March. 
IABLE B.4. Total Waterfowl Observed in 1986-87(a)

River

Segment (km)

$0-1$

$1-2$

$2-3$

3-4

4-5

5-6

$6-7$

$7-8$

$8-9$

9-10

10-11

$11-12$

$12-13$

$13-14$

14-15

15-16

16-17

17-18

18-19

19-20

20-21

21-22

22-23

23-24

24-25

25-26

26-27

27-28
Total Waterfowl, 1986-87

\begin{tabular}{|c|c|c|c|}
\hline Dec(b) & $\operatorname{Jan}$ (b) & Eeb(b) & $\operatorname{Mar}^{(b)}$ \\
\hline 300 & 345 & 24 & 53 \\
\hline 3000 & 6045 & 2838 & 2305 \\
\hline 10500 & 9240 & 1422 & 1400 \\
\hline 3160 & 4465 & 107 & 60 \\
\hline 510 & 540 & 40 & 35 \\
\hline 542 & 550 & 15 & 42 \\
\hline 148 & 565 & 382 & 83 \\
\hline 170 & 1205 & 147 & 80 \\
\hline 258 & 470 & 463 & 110 \\
\hline 53 & 40 & 80 & 87 \\
\hline 40 & 470 & 140 & 45 \\
\hline 433 & 420 & 570 & 26 \\
\hline 2195 & 1867 & 2165 & 340 \\
\hline 33 & 24 & 285 & 410 \\
\hline 355 & 547 & 246 & 60 \\
\hline 196 & 122 & 250 & 76 \\
\hline 173 & 40 & 334 & 129 \\
\hline 155 & 130 & 310 & 1110 \\
\hline 14 & 230 & 705 & 650 \\
\hline 15 & 110 & 290 & 20 \\
\hline 5 & 115 & 300 & 0 \\
\hline 300 & 220 & 416 & 25 \\
\hline 5 & 160 & 61 & 18 \\
\hline 51 & 202 & 19 & 27 \\
\hline 149 & 294 & 35 & 0 \\
\hline 97 & 243 & 44 & 31 \\
\hline 110 & 99 & 51 & 4 \\
\hline 30 & 10 & 23 & 2 \\
\hline
\end{tabular}

(a) Total may exceed the sum of coots, ducks, and geese because of unidentified watertowl.

(b) Cumulative total for three flights in December, five in January, four in February, and five in March. 
IABLE B.5. Waterfowl Observed in 1987-88

River

Segment (km)

$0-1$

$1-2$

2-3

$3-4$

4-5

5-6

6-7

7-8

$8-9$

9-10

10-11

11-12

$12-13$

13-14

14-15

15-16

16-17

17-18

18-19

19-20

20-21

21-22

22-23

23-24

24-25

25-26

26-27

Number of Waterfowl. 1987-88

\begin{tabular}{|c|c|c|c|}
\hline \multicolumn{2}{|c|}{ Ducks } & \multicolumn{2}{|c|}{ Geese } \\
\hline $\operatorname{Dec}^{(a)}$ & $\operatorname{Jan}(a)$ & $\operatorname{Dec}^{(a)}$ & $\operatorname{Jan}^{(a)}$ \\
\hline 0 & 0 & 0 & 0 \\
\hline 4363 & 0 & 70 & 0 \\
\hline 2985 & 70 & 70 & 20 \\
\hline 4 & 0 & 0 & 1 \\
\hline 2 & 0 & 0 & 0 \\
\hline 6 & 1200 & 0 & 0 \\
\hline 66 & 50 & 0 & 0 \\
\hline 754 & 235 & 501 & 0 \\
\hline 173 & 0 & 0 & 0 \\
\hline 152 & 70 & 400 & 0 \\
\hline 151 & 0 & 3 & 0 \\
\hline 476 & 116 & 5 & 0 \\
\hline 221 & 110 & 0 & 0 \\
\hline 177 & 0 & 0 & 0 \\
\hline 95 & 0 & 30 & 0 \\
\hline 572 & 0 & 0 & 0 \\
\hline 1830 & 21 & 14 & 0 \\
\hline 218 & 510 & 0 & 0 \\
\hline 401 & 0 & 0 & 0 \\
\hline 0 & 2 & 0 & 0 \\
\hline 3 & 0 & 151 & 0 \\
\hline 14 & 2 & 14 & 0 \\
\hline 4 & 0 & 20 & 0 \\
\hline 12 & 0 & 96 & 0 \\
\hline 218 & 0 & 30 & 1 \\
\hline 96 & 0 & 20 & 0 \\
\hline 0 & 0 & 0 & 0 \\
\hline
\end{tabular}

(a) Cumulative total for three flights in December and one flight in January. 
IABLE B.5. (contd)



Number of Waterfowl. 1987-88

\begin{tabular}{rrrr}
\hline & Coots & & \multicolumn{2}{c}{ Total Waterfowl } \\
\cline { 2 - 4 } Dec $^{(a)}$ & $\operatorname{Jan}^{(a)}$ & \multicolumn{1}{c}{ Dec (a) } & \multicolumn{1}{c}{$\operatorname{Jan}^{(a)}$} \\
45 & 0 & 400 & 0 \\
300 & 40 & 4478 & 40 \\
0 & 0 & 3355 & 90 \\
65 & 0 & 4 & 1 \\
130 & 0 & 67 & 0 \\
50 & 0 & 136 & 1200 \\
1300 & 50 & 116 & 100 \\
306 & 260 & 2555 & 495 \\
860 & 206 & 479 & 206 \\
315 & 100 & 1412 & 170 \\
3700 & 40 & 469 & 40 \\
746 & 475 & 4181 & 591 \\
114 & 870 & 967 & 980 \\
125 & 0 & 291 & 0 \\
125 & 0 & 250 & 0 \\
1100 & 0 & 697 & 0 \\
0 & 4 & 2944 & 25 \\
0 & 1200 & 218 & 1710 \\
0 & 0 & 401 & 0 \\
0 & 0 & 0 & 2 \\
0 & 0 & 154 & 0 \\
0 & 0 & 28 & 2 \\
100 & 0 & 24 & 0 \\
100 & 0 & 208 & 0 \\
0 & 0 & 348 & 1 \\
0 & 0 & 116 & 0 \\
& 0 & 0 & 0
\end{tabular}

(a) Cumulative total for three flights in December and one flight in January. 
PNL-6485

UC-11

\section{DISTRIBUTION}

No. of

Copies

OFFSITE

3 G. Stedman

Environmental Protection Specialist

I Corps \& Fort Lewis

Attn: AFZH-EHQ

Fort Lewis, WA 98433

10 DOE/Office of Scientific and Technical Information

\section{ONSITE}

DOE Richland Operations Office

J. J. Sutey

17 Pacific Northwest Laboratory

P. A. Beedlow

D. D. Dauble

D. W. Dragnich

L. E. Eberhardt

R. E. Fitzner

P. C. Hays

L. E. Rogers

J. A. Stottlemyre

R. E. Wildung

S. G. Weiss

Publishing Coordination (2)

Technical Report Files (5) 
